\title{
Not anointing, but justice? A critical reflection on the anointing of Pentecostal prophets in a context of economic injustice
}

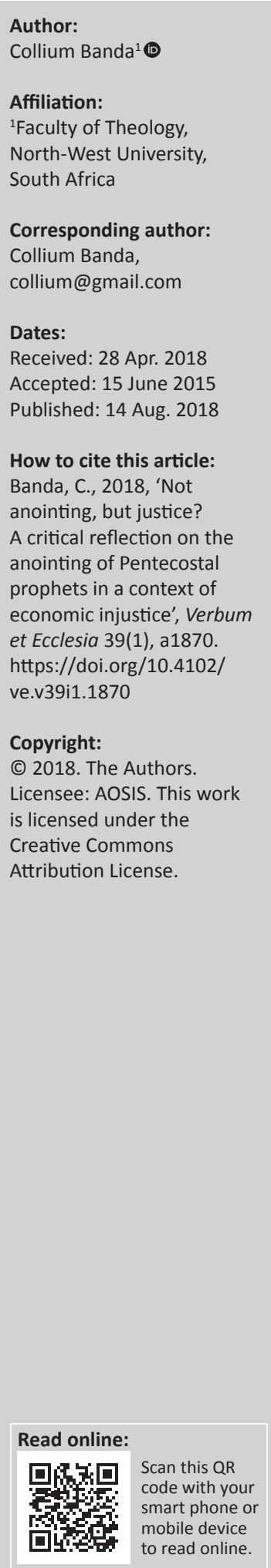

To what extent does the anointing of the Pentecostal prophets provide a meaningful way of responding to poverty in an unjust economic context? Using Zimbabwe as a case study, this article critically evaluates the growing reliance on the anointing of the Pentecostal prophets by many poor people as a way of responding to their economic poverty. The practice is considered to provide miraculous power to pave the way for a desired economic outcome. The article highlights that many people turn to the anointing of Pentecostal prophets as a form of spiritualised activism against unjust economic forces in the country. The article proposes that rather than anointing, seeking justice should be the adopted means of responding to unjust economic systems. It examines aspects that should inform the church's quest for economic justice.

Intradisciplinary and/or interdisciplinary implications: This study relates to the disciplines of systematic theology, public theology and sociology of religion by calling on Christians to allow other disciplines to inform their desire to eradicate poverty.

\section{Introduction and background}

Attendant to the 'prophetic craze' (Chitando, Gunda \& Kügler 2013:9) currently gripping Zimbabwe is the anointing of the Pentecostal prophets (Bulla 2015; Rupapa \& Shumba 2014). Pentecostal prophets employ what they call 'anointing' as a means of passing miraculous power onto their followers to attain prosperity in wealth, health and to overcome all spiritual threats to the human well-being. Although anointing is a popular concept among Zimbabwean Pentecostal prophets, it is difficult to define concisely. Pentecostal prophets anoint their followers by directly applying oil or water usually on the forehead. The prophets also use their clothing items or other objects deemed fit for use for anointing purposes (Magaya 2016a). Prophets also give out or sell articles they have prayed for such as water and oil to individuals for self-application by individuals at their convenience (Magaya 2015a). In general, Pentecostal prophets are regarded uniquely anointed by God, which implies that their activities such as prayers, words and presence are considered to have an anointing effect and therefore carry spiritual effects.

Zimbabwe's leading Pentecostal prophet, Walter Magaya (2015a), says with reference to anointing oil:
Anointing oil is a physical symbolism of God's healing and deliverance power. It is a point of contact in spiritual warfare and is a symbol of the Holy Spirit. It protects from deadly dangers and traps, and it does the cleansing and purification. It is the anointing of our Lord Jesus Christ and the Holy Spirit which is a powerful tool in spiritual warfare. The anointing oil destroys or breaks the bondage, burden and oppression caused by the devil because the enemy's yoke connects and binds you with sin, poverty, disease and limitation. The anointing oil therefore breaks all the yokes the devil is using to steal the promise God made to us, that of having dominion over earth and being seated in the heavenly places. (n.p.)

The text focuses on anointing oil but sheds insight into the whole principle and practice of Pentecostal prophetic anointing. Pentecostal prophetic circles view anointing as a means of ushering one into a state of blessedness resulting in healing and having the power to fulfil one's desires, particularly those seemingly impossible to attain given one's circumstances. Prophet Emmanuel Makandiwa is reported by The Herald journalists, Tendai Rupapa and David Shumba (2014), announcing: 'anointing oil unlocks all the doors of impossibilities in one's life. It will lubricate your lives and things will start moving smoothly'. In other words, an anointed person receives God's healing, liberating and enabling power. No wonder, there is such a great demand for Pentecostal prophetic anointing in Zimbabwe (Bulla 2015; Rupapa \& Shumba 2014). 
Economically, Zimbabwe is riddled with severe crippling poverty and suffering; Pentecostal prophetic anointing promises 'to pave the way for ... economic advancement' (Magezi \& Manzanga 2016:3). This article agonises over the effectiveness of the anointing of Pentecostal prophets as an economic response within a context of economic injustice. This article asks the question: to what extent is the anointing of the prophets a meaningful way of engaging the unjust economic context? Zimbabwe is used as a case study. In answering this question, the article first analyses the emphasis on anointing in Zimbabwean prophetic Pentecostalism. The following section highlights how anointing acts as a spiritualised activism against unjust economic systems. The succeeding sections show that prophetic anointing is insufficient to meaningfully respond to a context of economic injustice. Seeking justice is proposed as a more biblically orientated prophetic means of responding to economic justice. The article closes by proposing some aspects that should inform the church's quest for economic justice. It is hoped that a justice-orientated approach will prompt Christians in constructive activism for economic justice than the individualistic and laissez-faire approach in prophetic anointing. The purpose of this article is not to determine whether or not the African Pentecostal prophets are legitimate prophets of God, but to only evaluate the meaningfulness and usefulness of their use of anointing as a response to poverty in a context of economic injustice.

\section{The emphasis on anointing among Pentecostal prophets}

In this section, the emphasis placed on anointing among Zimbabwean Pentecostal prophets will be presented and examined.

\section{Anointing as a pre-requisite to success}

Prophet Walter Magaya, a leading Zimbabwean Pentecostal prophet, shows the importance of anointing in a sermon entitled Overtake and Maintain (Magaya 2016b) based on 2 Samuel 6:1-11. In the Samuel text, God blessed Obed-Edom and his household for taking custody of the ark of the covenant after King David's attempt to move it from Baalah of Judah to Jerusalem tragically ended with the death of Uzzah, who was struck by God for touching the ark to save it from falling off the cart. Magaya (2016b) uses this incident to emphasise the need for anointing before anyone undertakes any task. However, the failure of David's mission in Samuel was because of failing to follow God's procedures when moving the ark of the covenant. Magaya states, 'You need to be anointed in order for you to reach your desired goal'. Magaya uses the text to advise people against undertaking adventures without first seeking God's anointing. Interestingly, Magaya directs his criticism not to David who commissioned the failed mission, but to the unfortunate Uzzah, who died attempting to save the ark from falling from the cart. Prophet Magaya warns:

You should respect the anointing of God and never get used to it like Uzzah did. He thought he could assist God when in actual fact God does not require our assistance. The anointing of God changes your life. (n.p.)

As time and space do not permit this article to evaluate the problematic interpretation of the Bible in prophetic Pentecostalism, priority will be given to appreciating how the prophets arrive at their position on anointing. In the above quotation, Magaya (2016b) presents Uzzah as a victim of taking for granted the anointing of God because of his familiarity with the ark. On the other hand, the fortunate Obed-Edom is presented as one who recognised the anointing of God and respected it, resulting in God magnanimously blessing him and his family (Magaya 2016b). Magaya is silent on King David who commissioned the ill-fated adventure, who had God's anointing as the king of Israel. The rising question left unanswered is: Why did David's anointing as a king, as one who commissioned the mission to bring the ark, not prevent the disaster that led to God's killing of Uzzah? However, for Magaya, Obed-Edom serves as an example that ' $[t]$ he anointing of God changes your life' (Magaya 2016b). The implication is that anointing leads to a state of blessedness. Therefore, it is something that every Christian hungering for economic success must earnestly seek after.

\section{Anointing as receiving God's empowerment}

Anointing is significant to prosperity Pentecostals because it is a process of receiving God's enablement to achieve the impossible or to achieve a 'breakthrough' or 'pull down the strongholds' in Pentecostal terms. This is illustrated in Magaya's (2015b) sermon Drop the Old Donkey's Jaw Bone, based on Judges 13:15-17. In the biblical account, Samson broke two new ropes with which the Philistines had bound him and picked a fresh donkey's jaw bone which he used to massacre them. Magaya says when the spirit of the Lord came upon Samson, power spread into everything that bound him, which means 'anointing ... is for you to breakthrough'. Interestingly, in Samson, the effect of anointing spread into everything binding him, but in the above noted case, David's kingly anointing did not spread to the people like Uzzah employed in the king's mission to bring the ark of the Lord. Nonetheless, in Magaya's understanding, the specific purpose of anointing is to give the believer the power to triumphantly overcome all hindrances to one's material prosperity. For Magaya, 'property follows anointing'. He advises all who want to flourish materially of their 'need to pray to God so that $\mathrm{He}$ will anoint you enough to get whatsoever you are in need of' (Magaya 2015b). Magaya adds:

Whenever you are anointed enough there is a certain level that
you could reach and you will attract a certain group of people.
The higher the anointing the higher the level. You will only get
married when you are anointed enough for marriage and you
will also have a house if you are anointed enough for it. When
the anointing comes it will change your levels, friends and even
your environment and it will bring good news to your life. (n.p.)

In the above quoted text, firstly, only the anointed ones have access to wealth. Therefore, wealth is elusive to those 
without anointing. Secondly, the size of one's anointing determines the level of access to wealth; those who are greatly anointed have greater access to wealth. However, Magaya's (2015b) view that it is anointing only that opens access to wealth is faced with the question of how to explain the observable fact of many wealthy atheists and blasphemers. Nevertheless, for Magaya, anointing is necessary to the acquisition of material wealth. He says, 'You need to anoint everything around you. As you anoint everything around you speak about the favour of money among other things' (Magaya 2016b). It is common to see small bottles of anointed oil or water hanging under rear view mirrors in the cars, homes and shops owned by the followers of prosperity prophets. The emphasis explains why prosperity Pentecostals constantly seek anointing from their prophets and pastors. Being constantly anointed functions as a way of keeping one's anointing current and can also be seen as a way of enlarging one's anointing. ${ }^{1}$ Hence, an important component of a typical Pentecostal worship service is the invitation to all believers to come and be anointed or to receive a new anointing. Ultimately, Magaya's emphasis on the necessity of anointing in the quest for material successes bolsters the position of the pastors and prophets as divinely anointed people whom Christians must rely on for their anointing. This further puts into perspective why anointed objects such as anointed oil and anointed water are in high demand in prosperity Pentecostal churches.

\section{Anointing as breaking of the curse}

At the root of the Pentecostal emphasis on anointing is the firm belief that poverty, suffering and the failure to succeed are a result of a curse. Therefore, the principal role of anointing is the breaking of curses in people's lives. Anointing is considered to bring deliverance and therefore a means of fighting poverty and suffering. Therefore, anointing functions as a spiritual means of engaging the formidable evil forces. Prophet Walter Magaya's (2015a) sermon on anointing oil emphasised that anointing functions as a means of transcending obstacles of one's endeavours. Magaya explains that anointing oil 'is a physical symbolism of God's healing and deliverance power'. However, the anointed objects he uses are not just limited to oil, for he is known to have used water (Chaya 2017), cucumbers (Chaya 2016) and even articles of clothes that he has worn before (Magaya 2016a). Therefore, his body contains God's anointing that can be transmitted to other people. The following lengthy excerpt shows the dynamics that make anointing a tool of engaging one's obstacles, Magaya (2015a):

It is a point of contact in spiritual warfare and is a symbol of the Holy Spirit. It protects from deadly dangers and traps, and it does the cleansing and purification. It is the anointing of our Lord Jesus Christ and the Holy Spirit which is a powerful tool in spiritual warfare. The anointing oil destroys or breaks the bondage, burden and oppression caused by the devil because the enemy's yoke connects and binds you with sin, poverty, disease and limitation. The anointing oil therefore breaks all the yokes the devil is using to steal the promise God made to us, that of having dominion over earth and being seated in the heavenly places. In P.H.D [Power Healing and Deliverance] Ministries, the anointing oil is one of the major anointed mantles of the Ministry that has brought thousands of testimonies. (n.p.)

While in this text anointing specifically refers to oil, other objects like water can also be referred to. According to the text, anointing brings the active presence of God, which protects the anointed person from harm; it empowers the anointed person to triumph over evil obstacles to one's success. In other words, the anointing opens the doors and pathways that lead to economic prosperity, health and success in all other areas.

While time does not permit for a detailed analysis of the use of the Bible in prophetic Pentecostalism, three problems are briefly noted in the above discussion. Firstly, the prophets tend to rely on proof-texting to support their position on anointing. Secondly, the main purpose of anointing in the Bible was not for projects of self-interests and selfadvancement, but the work of God, and in many cases anointing came with severe suffering and personal losses, as testified in Jesus Christ's example. Thirdly, anointing in prophetic Pentecostalism functions as a form of a luck inducing magic which resonates with the traditional African reliance on magical charms.

\section{Anointing as spiritualised activism in a context of economic injustice}

A meaningful evaluation of the popularity of the anointing of Pentecostal prophets must seriously consider how it is a form of spiritualised activism against economic injustice. This section discusses how prophetic anointing functions as a form of spiritualised activism.

\section{The miraculous power to engage unjust economic structures}

Pentecostal prophetic anointing is much visible as a means of confronting the oppressive, exploitative and corrupt economic structures that inhibit ordinary citizens to flourish economically. Several studies link the emergence and growth of Pentecostal prophets in Zimbabwe to the collapse of the national economy under former President Robert Mugabe's rule (Biri \& Togarasei 2013; Chibango 2016; Chitando \& Biri 2016; Magezi \& Manzanga 2016; Mahohoma 2017; Maxwell 1998; Vengeyi 2011). Although the recently ushered in post-Mugabe era is relatively less brutal and the new President Emmerson Mnangagwa has promised to democratise the economy, besides a façade of peace and tranquillity, life in Zimbabwe remains far from being better for many ordinary people. Many poor people continue to face the very same economic struggles they faced in the Mugabe-ruled Zimbabwe. The struggle for economic survival can be seen behind the growth of prophetic Pentecostalism in many other African countries.

Indeed, Africa has a long-standing history of unjust economic structures because of the patriarchal structures 
that economically marginalised women and the racially segregated colonial economic policies that marginalised black people. In their insightful analysis of the problem of inequality in Zimbabwe, Mazingi and Kamidza (2011) highlighted that just like in the colonial era, postindependence Zimbabwe continues to be a context of economic injustice. However, while racial segregation was the prominent driver of economic injustice in the colonial era, corruption and greed thriving on lawlessness and broken public leadership are some of the major drivers of economic injustice in present Zimbabwe. In 2017, the international corruption watchdog, the Transparency International Zimbabwe (TZI) published a brief report entitled Understanding Bribery in Zimbabwe (2017). It reported that in many instances officers in service centres used delaying tactics to induce people to bribe them. The prevalence of such hurdles means that life is a serious challenge for many ordinary people who either have no means of paying the demanded bribes to obtain their daily necessities or have no power to avoid being asked to pay a bribe. Therefore, many people are attracted to the anointing of the prophets because of its promise to enable them to break through the hurdles placed by corrupt officials on their economic survival.

Furthermore, TZI analysed that in Zimbabwe, although corruption such as bribery is committed by individual actors, it actually happens at the institutional level. As noted by TZI (2007):

While bribery is committed by individual actors, it goes beyond the individualistic act and sees the network of power relations endorsed by institutions from which actors derive their power bases. (n.p.)

This statement highlights the hierarchical structure of oppressive and exploitative systems that the ordinary people have to wade through for their economic survival. The analysis by TZI means that the official demanding a bribe to issue a driver's licence, or the traffic policemen demanding bribes from commuter omnibuses, may be acting within a chain of several higher officers with whom the bride would be split. Therefore (TZI 2017):

Bribery ... mirrors the decay and disintegration of key public and private institutions - ones with monopoly and control over key political, economic and social services that citizens and business require. Such services include education, justice, housing, regulation inter alia. Bribery is therefore a reflection of how public institutions have been captured by self-interest of their agents, citizens and business. (n.p.)

In other words, bribery and all the other injustices thrive because the public institutions have been taken captive by selfish interests of those who administer them. In such a state of vulnerability, many turn to anointed objects hoping that they will, for example, prevent the corrupt admissions officer at a college from demanding a bribe to enrol them as a student, or the housing officer at the local municipality from demanding a bribe to allocate them a residential stand. Therefore, through anointing, Pentecostal prophets empower their followers to engage the economic space riddled with injustice. In such a case, anointing oil is used with prayer of claiming, binding and pulling down of strongholds.

\section{The miraculous power to thrive in failed national economy}

In many African countries, where economic survival is a daily struggle, 'socio-economic and political paralysis has provided a fertile ground for the emergence and growth of the prosperity gospel' (Banda 2016:153). It troubles many Zimbabweans that their black-led independent government inherited a 'relatively developed and diversified ... robust agro-based economy ... [with] ... flourishing mining and manufacturing sectors' (Mazingi \& Kamidza 2011:325) but dismally failed to maintain it and grow it. Many black Zimbabweans have become disillusioned with their own national independence and are greatly dismayed at their government's lack of visionary capacity to dream and implement economic policies that could bring a flourishing national economy. It is disturbing that since 1980 each economic policy implemented by the government has left the economy poorer than before, resulting in unprecedented high levels of national food insecurity, unemployment, deindustrialisation and international migration (Chung 2006:296; Mazingi \& Kamidza 2011:328-342; Raftopoulos 2009:219-227). To a large extent, reliance on the anointing of Pentecostal prophets in Zimbabwe can be viewed as a quest for the miraculous power to survive the neglect by the national government. Social security is low and often given on political partisan lines, which means that those who do not support the governing ZANU-PF have to fend for themselves.

The dismal failure by the government to provide effective economic leadership resulted in the informalisation of the national economy classified by Jones (2010:286) as 'kukiyakiya economy'. ${ }^{2}$ Concentrating on the turbulent 2000-2008 period, Jones (2010:285,296-297) decried that Zimbabwe's national economy had informalised to the extent that 'nothing [was] straight' any more. Consequently, Zimbabwe's mainstream economic life became characterised by dodgy informal activities that were once despised as actions of lazy people and scoundrels only interested in easily gained money or as tsotsis [criminals and crooks] (Mpofu 2011:14). The national economic vision has become characterised by endless announcements of yet to be fulfilled series of megadeals signed with Eastern countries, mostly China, and occasionally neighbouring South Africa. In the absence of effective national economic leadership and therefore having to resort to ukukiya-kiya and ukutshaya amdili [doing deals], the anointing of the prophets becomes extremely important and urgent to enhance one's self-reliance. The anointing of the prophets carries the promise to enable the believer to successfully unlock the door to great opportunities.

2.Kukiya-kiya seems to be phonetically derived from the English word 'key' to refer to a situation where the right key is not avalable or unknown, so one fiddles with a situation where the right key is not available or unknown, so one fiddes with water Van der Merwe 2017:247). Jones (2010.286) says kuklya-klya 'suggests cleverness, dodging, and the exploitation of whatever resources are at hand, all with an eye to self-sustenance'. 


\section{The value of anointing in prompting the poor to reject economic injustice}

The anointing of the prophets is useful and important in prompting the agency of the poor and powerless to realise the undesirability of economic injustice and the need to dislodge it. Anointing therefore functions a spiritualised means of engaging the context of economic injustice. According to Prophet Magaya (2015c):

Everyone here on earth is from heaven and when man (sic.) was placed on earth he was given dominion over earth, however and surprisingly we have become colonised by earthly things such as $\mathrm{HIV}$, cancer, poverty, divorce to mention but a few. By nature of human creation it means we are kings just like what the Holy Bible says Jesus is the king of kings and we are the kings. Thus we must be colonised by the Kingdom of heaven and live the culture of heaven. (n.p.)

For Magaya (2015c) to accept suffering, and submit to it, is to be colonised by it, and Christians must reject it because they belong to heaven without pain and suffering. The use of the words 'colonise' and 'kings' galvanises the poor to reject all suffering in this world and to spring at once into action for a better life. Therefore, he affirmatively condemns all preachers who preach that people must accept suffering and poverty in this world. He states (Magaya 2015c):

The worst person today is the Pastor or Apostle who is still teaching congregants that we shall rejoice in heaven and we must be ready to suffer here on earth. That's heresy, you are busy preaching doom in those churches right on the altar by the pulpit (sic.). (n.p.)

Effectively, poverty, suffering and pain must be rejected and efforts must be vigorously undertaken to dislodge them. Essentially, Pentecostal prophets have prompted many into formal and informal entrepreneurship in Zimbabwe. Magaya encourages his congregants to be entrepreneurial. Chibango (2016:65) amplifies Magaya charging his congregants, 'If you are a member of Prophetic Healing and Deliverance Ministries (PHD) and you rely on your salary then you are daft'. With such a charge and armed with the anointed objects, many people take risks and undertake various business adventures. A study is needed to measure the economic activity and wealth created as a result of the prophets calling for their congregations to be entrepreneurial (Chibango 2016:65). However, the many taxis and vehicles and business premises with stickers bearing the various prophets' portraits and the many workers and university students wearing regalia bearing their names are evident signs that many people are motivated by anointing from the Pentecostal prophets.

\section{The problem of prophetic anointing in responding to economic injustice}

An ensuing question is: How effective is the reliance on the anointing of Pentecostal prophets in contexts such as Zimbabwe where unjust economic systems prevail? This section answers this question.

\section{Undermining the human element in unjust structures}

A serious problem with the anointing of the Pentecostal prophets is the undermining of the human element in unjust structures of economic life by over spiritualising socioeconomic reality. Indeed, biblically and theologically, it cannot be denied that poverty and economic injustices are ultimately spiritual problems resulting from the fall of humanity. However, these are not just spiritual issues, for human beings implement and run economic structures. Therefore, the tendency of Pentecostal prophets to uncritically prescribe faith and anointing while leaving sociopolitical and economic structures unattended is unproductive. It is necessary to attend to the poor and corrupt national leadership responsible for the economic crisis in Zimbabwe. As already noted by TZI (2017), the endemic problem of bribery and corruption 'mirrors the decay and disintegration of key public and private institutions - ones with monopoly and control over key political, economic and social services that citizens and business require'. In such a situation, reliance on anointing only without transforming the structural economic injustice is an insufficient solution. The decayed and disintegrated public and private institutions need to be saved.

Agbiji and Swart (2015:8) highlight that 'religious practitioners have often encouraged "God-talk" that weakens the resolve of masses to rise up against unjust political and economic systems in Africa'. Indeed, it is common in Zimbabwe for '[i]rresponsible government systems and unjust international policies ... [ to ] go unchecked as all blame is placed on demons' (Chibango 2016:72-73). Likewise, Chitando and Manyonganise (2011:101) note that church leaders in Zimbabwe often shun critical reflection on the details of socio-economic situations and uncritically seek divine intervention in a way that 'absolve[s] human beings of their responsibility in creating the crisis as well as their role in its resolution'. This undermines and suppresses the activism of the oppressed poor to overturn the oppressive structures. Therefore, while seeking divine intervention remains important and necessary, it should not be employed to 'replace responsible actions that are geared towards fighting unjust systems' (Agbiji \& Swart 2015:8). As already noted from the report of TZI, corrupt individuals capture and privatise public institutions to only serve and promote their selfish interests, which highlight the need for institutional and structural reform in addressing poverty. Therefore, behind economic injustice are human structures, human institutions, people, policies, practices, beliefs, attitudes, convictions and habits that need to be confronted, challenged, abandoned and transformed.

\section{The paganisation of African human capital}

Reliance on the anointing of the prophets ultimately paganises African human potential. Paganisation is used here to mean regarding African human potential as so devoid of God (above and beyond the biblical assertion of the fallen 
nature of all humankind) and therefore cursed to the extent of barrenness of any capacity for progress without the aid of a Christian orientated religiosity. Although operating outside radical prophetic Pentecostalism, but a leading prosperity Pentecostal voice in Zimbabwe, Pastor Tom Deuschle (2003:71) avers, 'Without an economic revival based on biblical principles, we can say goodbye to Africa'. In other words, Africa's economic panacea lies in obeying the Bible. Unfortunately, besides encouraging people to be faithful Christian witnesses in their workplaces, to be connected to other successful Christian businesspeople and urging them to initiate their own businesses, Deuschle's book does not detail the intricacies of a Bible-based economic vision and, therefore, by default upholds Western capitalism. However, without dismissing the value of obedience to the Bible in spurring economic revival in Africa, one is left to wonder about non-Christian countries such as China, Japan and even United Arab Emirates that have booming economies. If those countries and many others did not need biblical obedience to experience economic revival, why is it then particularly necessary for African economic revival? One is left wondering, what is so wrong with African human capital that, unlike other races of the world, it can only economically thrive when penetrated by the Bible? The unfortunate logical conclusion of this view is the undermining of African human capital as so pagan and so beastly that on its own without religious influence, it lacks the innate strength for any progressive but savagery acts only.

This query does not dispute both the relevance and necessity of the Bible in economic revival, but highlights that Christians often apply simplistic logic in their economic and political solutions to poverty in Africa. Furthermore, this affirms and fuels the age-old belief of a blessed Christian Europe and a cursed pagan Africa. It also overlooks the obvious fact that the modern unparalleled economic growth of the world's leading economies occurred within an aggressively deChristianising and secularising context, while massive Christianisation in Africa has occurred alongside massive economic impoverishment (Vengeyi 2011:234). Mugambi (1995:33) mourns the apparent contradiction that contemporary Africa remains, perhaps, the most 'religious' continent in the world, while its peoples are continually the most abused of all in history. Pentecostal prophets need to grapple with this dirge (Mugambi 1995):

How could it be that the peoples who continue to call on God most reverently are the ones whom God seems to neglect most vehemently? Could it be that irreligion is the key to success, and that religion is the key to backwardness? (p. 33)

Wrestling with Pope John Paul VI's call for the enhancement of the 'God-given potential' of the poor, Speckman (2007:xvii, 1) finds that Africans rank among the world's poor people 'because they constantly and wilfully undermine their own [human] potential'. Pentecostal prophets undermine African human potential by not promoting the development of human potential and human responsibility but by placing a heavy uncritical reliance on religiosity for economic development. This results in a magical view of economic life without an ethic of work by believing that it is the right anointing that leads to success. Aconsumeristic preoccupation with the quickest and less demanding way of amassing material wealth diminishes any interests in developing the human potential and responsibility to create and manage the economy. The anointing of the prophets inculcates an individualistic response to poverty that is only concerned with one's improved personal circumstances while ignoring the broader causes of poverty.

\section{Places the blame for the existence of poverty on the poor only}

Furthermore, reliance on the anointing of the prophets places the blame for the existence of poverty on the poor. Zimbabwean Pentecostal prophets are generally silent about the existence of oppressive and unjust economic justice but more vocal on blaming and condemning the poor for lacking the spiritual condition that leads to material wealth. For instance, Mahohoma (2017:4) shows Magaya preaching that those who give less money to the church should not expect God to answer their prayers because 'God answers those who put more. Put more and become rich, richer and richest'. Such statements only blame the poor for their own poverty. Furthermore, the statement blames the poor in a way that mocks their state of poverty without paying attention to socio-economic and political structures inhibiting the poor from progressing economically.

To some extent, Zimbabwe's government officials have adopted blaming the poor for their poverty. On a few occasions in Zimbabwe, government officials including the governor of the country's Reserve Bank have called on the citizens to pray for the economic success of the country. While this may be viewed as a noble recognition of the power of prayer and the need for God's blessings and guidance on national economic developments, these government officials do not show much commitment to sound management of the economy. Furthermore, these empty requests for prayer by government officials not committed to judicious management of the national economy shift the responsibility of poverty in the country to the poor by indirectly blaming them for not praying enough for the needed national economic transformation. Without activism, anointing leads to lazy scapegoating as the blame for poverty is passed to imagined spiritual curses. This leads to resignation and acceptance of status quo.

\section{The promotion of dependency that enriches the prophets and pastors}

While the existence of poverty is only placed on the poor, Pentecostal prophetic movements create and promote dependency on the prophets and pastors that ends up enriching the clergy while further impoverishing the poor. Pentecostal prophets are wealthy; much of their wealth derives from the people's dependence on them (Mahohoma 2017:3). As Mahohoma (2017:3-4) highlights, when people visit Prophet Magaya, they stay at the guest houses run by the church, making the houses a source of income for 
the prophet. The building of guesthouses or hotels specifically to accommodate people who visit the prophet creates a shrine. This, in turn, results in pilgrimages as people have become so dependent on the prophet and frequently need to consult him for prophetic services. The problematic issue is that the pilgrimage is promoted in a way that leaves the prophet vulnerable to charges of using it as a source of income for himself. Furthermore, while the prophets preach that people must constantly be anointed, yet the anointed mantles like oil and water are often sold and not given for free. The prophet's statement, 'Even in church if you were anointed in 2014 it does not mean that you are still anointed in 2015' (Magaya 2015b), creates a dependency on the prophet that enriches the prophets. This does not mean that the prophets should not own businesses; but it is an entirely different thing when they promote their businesses by creating a spiritual vacuum for their followers so that they depend on their businesses to fill that vacuum. A common feature with prophets Emmanuel Makandiwa and Magaya includes spectacular all-night meetings that often attract many foreign visitors. Makandiwa often hosts what he calls Judgement Night and annual New Year's eve meetings called Cross-Over Night to mark the crossing from the old year into the new one. Magaya also runs what he calls Night of Turnaround. These are oversubscribed meetings often attracting prominent international visitors. Mahohoma (2017:3) dismisses the validity of these prayer meetings intended to lead people into personal socio-economic revival by saying: 'All-night gatherings tend to be fundraising rather than Gospel preaching'. The heavy emphasis on money in these prayer meetings opens the prophets to the criticism of 'commercialising church items in order to amass wealth' (Chibango 2016:60).

\section{The need to move from anointing to justice}

It is proposed that the prophetic concern for poverty prioritises the justice factor. The proposal for justice does not seek to undermine the spiritual dimension of poverty. This proposal stems from a firm belief that poverty in most of Africa thrives on unjust economic structures. The dismantlement of these institutions must be prioritised in quest for economic well-being for the poor. It is not enough to provide spiritual solutions that do not transform unjust economic structures.

\section{Poverty as a justice problem}

The struggle for economic well-being of the poor is essentially a struggle for economic justice and therefore not just a spiritual problem. Reflecting on the economic justice in his South African context, Dumisani Methula (2014:108) argues that 'at the root' of social problems such as the prevalence of crime, substance abuse, alcoholic lifestyles and juvenile delinquency 'lies the fundamental structural crisis of economic injustice and elite policies that only serve those with economic might, political power and social privileges'. Old Testament scholar Obvious Vengeyi (2011:230) links poverty and injustice in Zimbabwe by saying the country's poverty 'is a result of human manufacturing by economic systems that serve and are manipulated by the rich and powerful'. In agreement with economic analysis by Mazingi and Kamidza (2011), Vengeyi (2011:230) also recognises the historical colonial economic imbalance that favoured and in many ways still continues to favour the white people against the black people. Vengeyi (2011:230) further observes that in independent Zimbabwe, some government policies 'are favourable to the elite', while 'corruption has become endemic in society - it has become one of the impoverishing factors'. The endemic levels of corruption are of such a nature that condemning individuals for their predicament, as popularly performed by Pentecostal prophets, is unwarranted (Vengeyi 2011:230). This affirms poverty as a justice issue.

\section{The significance of justice to biblical prophets}

Methula (2014:114) observes that the 'Bible is full of passages that place the call for justice in the centre of its teaching'. Consequently, '[j] ustice is an important issue in all societies and it is a central theme in Christian theology' (Methula 2014:114). The ministry of biblical prophets was driven by the shalom vision of the future 'healing and wholeness of human relationships, of the well-being of creation, and of the covenantal between Yahweh and Israel' (De Gruchy 1995:44). Authentic Biblical prophets often distinguished themselves from false prophets by insisting that genuine spirituality translate into social justice for 'shalom ... is inseparable from the doing of justice' (De Gruchy 1995:44). Subsequently to be a true prophet of God included being an advocate of social and economic justice.

Strydom (2000:198-221) lists that 8th century prophets contended with an "'astonishing variety" of injustices' that included the confiscation of the land and assets of the poor, debt slavery, exploitation of widows and orphans, denying the poor and powerless legal justice, unfair taxes and levies and taking of pledges from the poor and powerless, selfenrichment and exploitation of the poor, corruption in business and trade, exploiting one another and exploiting the poor and denying them fair treatment. The condemnation of 'selling the poor for a pair of sandals' in Amos 2:6 and 8:6 points to a desperate situation where the ordinary people were exploited, oppressed and immersed in abject poverty that left them socially weakened without human dignity. This situation shows that 'the poor were crushed with impunity' (Vengeyi 2011:229). This was hastened by the fact that the 'law courts were not there to serve the poor but the rich' (Vengeyi 2011:229).

The prophets neither turned a blind eye to officially sanctioned structural injustices against the poor, nor did they blame the poverty of the poor to their lack of faith. In fact, '[f]alse prophets ... proclaim[ed] shalom without justice (Jr 14:13)' (De Gruchy 1995:44). As an example, the prophet Isaiah (10:1-2) condemned rulers for crafting unjust and oppressive laws to deprive the poor of their rights, for denying justice to oppressed people and exploiting the 
widows and the orphans. Similarly, social justice is such a serious concern to the prophet Amos that he can be described as 'the great prophet of social justice' (Strydom 2000:170). As an advocate of social justice, Amos condemned the exploitation and oppression of the vulnerable members of the society (Am 2:6-7a; 4:1; 5:11) and corruption in the judiciary (Am 5:7,12). Amos emphasised that 'land, economic and property ownership disparities were the factors that caused poverty and not spirituality of the individuals. The system was against the poor' (Vengeyi 2011:228).

A major function of the prophets was calling for equality of all citizens before the law and economic equitability so that the economic resources will benefit all the citizens to ensure that the vulnerable are protected and provided for. The prophets demonstrated commitment to God's justice by their unshaken resilience in condemning and warning civil authorities to 'let justice roll on like a river, righteousness like a never-falling stream' (Am 5:24, also Is 1:15b-17; Mc 2:1). This meant that the prophets were constantly unwelcome guests or inhospitable hosts to civil authorities who oppressed their poor and powerless subjects.

It is unfortunate that many Pentecostal prophets are not known for being concerned with social injustice. Of course, some do charity work, but their charity leaves oppressive structures untransformed. Unlike the feared and loathed biblical prophets whose commitment to justice made them unpopular to the evil and oppressive civil rulers, some contemporary Pentecostal prophets appear to be well celebrated by oppressive and corrupt civil authorities. Many Zimbabwean Pentecostal prophets are celebrated for their amassing of great wealth rather than voicing against social injustice. One can say for these prophets voicing against state-sponsored systemic injustices could put their wealth at risk from offended government officials. The Old Testament prophets are examples that one cannot claim to be God's prophet and yet turn a blind eye to the social injustice and even benefit from it as done by prominent Zimbabwean Pentecostal prophets.

\section{Aspects that demand the prophetic prioritisation of justice}

What aspects should inform the prophetic tackling of systemic economic injustice in Africa? This closing section proposes four important aspects that can assist the church's prophetic prioritisation of justice.

\section{Awareness of the church's God-given responsibility to protect the poor}

A tenet that runs throughout the whole of Scripture is God's averred commitment to the poor and powerless. The Bible is unequivocal about God's preferential option for the poor who, on account of their powerlessness, lack the social, economic, political and legal means to demand a just and equitable distribution of economic resources.
This commitment is prominent in the entire Bible. As Isaiah (Is 58) reminded the people of Judah:

if you do away with the yoke of oppression ... and if you spend yourselves on behalf of the hungry and satisfy the needs of the oppressed then your light will rise in the darkness, and your night will become like the noonday. (vv. 9b-11)

According to this text, 'a right relationship with God is simply unthinkable without the impulse to come to right relationships with fellow human beings' (Bedford-Strohm 2008:145). Consequently, the biblical idea is that 'right relationships with fellow human beings are not a sacrifice we have to bring in order to satisfy God's commandments but resource for a good life' (Bedford-Strohm 2008:145). Good relationships among human beings are good not only because they please God, but also are necessary as resources for a good life. Unjust structures are not just evil ontologically, they are evil teleologically by withdrawing and withholding from the poor and powerless the resources needed to flourish as dignified human beings. God has placed a solemn responsibility on the church to protect the poor and powerless members of the society. As already pointed out, one of the important roles played by the Old Testament prophets was pleading for the cause of the poor, the alien, the widows and the orphans (De Gruchy 1995:40-44).

Protecting the poor and powerless must be Christologically based. Christ, the fulfilment of the Old Testament prophecies, unequivocally expressed a firm commitment to the poor and powerless by his example and teachings. Indeed, Christ made statements that appear to view poverty spiritually and not materially (Mt 5:3). However, he also made clear statements that prioritised responding to the needs of the needy, the poor and powerless (Lk 10:25-37; Mt 25:35-40). Drawing from James Dunn, Longenecker (2010) emphasises that Jesus encountered the poverty of the poor people he ministered to as:

A social condition, with social causes, often the result of greed and manipulation ... [by] those members of society who controlled economic and political power, and were willing to use that power ruthlessly. (p. 120)

Similarly, Galatians 2:10 and James 1:27 are some of the New Testament passages that show that the church viewed responding to the poor and powerless as 'a practice integral to an embodied proclamation of the good news' (Longenecker 2010:155).

\section{Promoting the development of the human potential of the poor}

A biblically informed prophetic quest for economic justice must promote the development of the human potential of the poor. Reliance on the anointing of prophets prompts the following question: at what point does an individual become independent and weaned from the prophets to maturity and accountability as a full-fledged human being reliant on God? At what point do poor Africans take responsibility and stop blaming imagined evil spiritual powers for 
their poverty? Reliance on prophetic anointing infantilises whole communities by disabling their power to exercise their human potential. Kretzschmar (2002:48) amplifies Gregory Baum's concern about 'infantile religion' that 'makes people dependent, passive, uncritical, gullible, immature and vulnerable when separated or not linked with the leaders'. Reliance on the anointing of the Pentecostal prophets leads to an infantile religion by mainly promoting the idea that human beings cannot fulfil their God-given mandate to creatively subdue the earth and all in it unless they have the prophets' anointed mantles in their pockets. Ultimately, the people are commodified, subdued and dominated by the prophets resulting in their serious depersonalisation and dehumanisation.

There is therefore an urgent need for the church to assist poor Zimbabweans to develop their God-given human potential. Bedford-Strohm (2008:157) draws attention to the document of the Advisory Chamber of Social Order of the German Protestant Churches Federation entitled Just Participation: Empowerment for Personal Responsibility and Solidarity (2006) that defined poverty as 'a lack of participation'. This means that poverty should not only be limited to the lack of material things even though they contribute to the quality of life. Much more, poverty is the 'inadequate participation in society' (EKD, in Bedford-Strohm 2008:158) that leaves capable people without the power to 'become responsible for themselves so that they are not dependent on welfare' (Bedford-Strohm 2008:158). Therefore, instead of dishing out anointed mantles to the poor, Pentecostal prophets need to creatively consider strategies of developing human potential by equipping and empowering the poor to be imaginative and responsible socio-economic players (Korten 1990:67; Myers 2011:133-143). To Speckman (2007:xxvi-xxvii), the disciples' healing of the crippled man instead of giving him alms in Acts 3:1-10 shows that a useful strategy of addressing poverty aims beyond giving crutches and wheelchairs to providing "'sturdy legs" for destitute communities to stand on'. Therefore, the 'exclusion of the poor is irreconcilable with the Christian faith. The goal of the economy should be on the participation of all members of society' (Bedford-Strohm 2013:31). Much to its credit, Tom Deuschle's Building People, Building Dreams: How a Church Can Change a Nation (2003) recognises the need for Christians to be equipped for entrepreneurial activities, but emphasises personal piety in a way that ends up downplaying the advantage of being well-equipped.

\section{Awareness of the complexity of economic issues}

The church's promotion of the development of human potential of the poor must recognise that the economy is a complex, highly technical and specialised reality. The success or failure of the economy cannot just be reduced to a single factor of religious condition. The struggle to overcome poverty 'needs competent expertise in economics, political science, psychology and education' (Bedford-Strohm 2008:144-145). According to Nürnberger (1994:136), ‘[We need a] multidimensional and comprehensive approach'. In other words (Nürnberger 1994):
Economic measures must become part of an integrated religious, cultural, social, economic and political programme. Theology should become a partner in an interdisciplinary team, while the local church should be part of the main swell of public initiative and responsibility. (p. 136)

The passion to eradicate poverty by the prophets, pastors and theologians does not mean that they individually possess all the required specialised knowledge, skills and training to embark on a successful campaign to eradicate poverty. Therefore, they need to partner with other disciplines and consult and involve well-informed technical experts in their mission to eradicate poverty. A serious problem is that the 'theological training that most church leaders have does not pay attention to crucial issues such as politics and economics' (Chitando \& Manyonganise 2011:102). This means that although zealous to eradicate poverty, many ministers are not sufficiently equipped to see the whole puzzle and the ligaments of the economic sphere. Moreover, many church ministers consider a careful technical analysis of economic situations a waste of precious time and even a demonstration of lack of faith.

Yet, it is essential to first study the situation through interdisciplinary, participatory and inclusive analysis to gain knowledge of what is needed (Nürnberger 1994:136). Poverty is a complex issue. Strategies and policies of addressing poverty 'should emerge from analysis, not from ideological [and spiritual] preconceptions' (Nürnberger 1994:136). It requires a comprehensive approach. As Chitando and Manyonganise (2011:102) put it, 'there is need to increase the levels of political [and economic] literacy of many [church] leaders'.

\section{A theology of church and state that promotes just rule}

A meaningful response to economic injustice needs a sound theology of church and state to empower and guide the church to be a conscience of the society that promotes the making and upholding of just laws. A sound theology of church and state will save many church leaders from easily falling prey to empty nationalistic rhetoric (Raftopoulos 2009:227). A well-informed theology of church and state should empower church leaders to play a constructive and justice-orientated role. It is beyond the focus of this article to discuss the various theological debates on the church and state, but to emphasise the importance of a well thought out theology of church and state in the church's promotion of economic justice. Many Zimbabwean Pentecostal prophets have shown to be easily co-opted by the state; this reflects a lack of understanding of the uniqueness and holiness of the church (Chitando, Manyonganise \& Mlambo 2013:164; Manyeruke \& Hamauswa 2013:289). From another angle, prophets also co-opt the state by openly supporting its controversial programmes such as Prophet Magaya's purchase of the biography of the former president's wife, Mrs Grace Mugabe, for $\$ 50000.00$ at a fundraising dinner (The Herald 2015). While some churches weaken their power 
of political influence by uncritical aloofness from the state, many Zimbabwean Pentecostal prophets have adopted uncritical closer affinity to the state which weakens their power to criticise state injustices.

A fruitful theology of church and state requires analytical neutrality. This critical neutrality is based on the fact that the church is first and foremost a holy entity belonging to Christ (Col. 1:18). Therefore, the church is primarily loyal to Christ its Lord and Saviour; consequently, its mission, work and interests ought to be driven by Christ's comprehensive soteriological vision of saving human beings from the power of sin and its effects, of giving abundant life to all (Jn 10:10), of protecting the vulnerable members of the society (Jas 1:27) and promoting social peace and justice (1Tm 2:1) to allow people to fulfil the cultural mandate (Gn 1:26-28). Rather than aloofness or blind loyalty to political parties and political systems, the church must maintain a critical position informed by God's shalom vision in both its immediate and eschatological dimensions. A sound theology of church and state must realise the church's God-given dual responsibility of reigning over its members to be loyal and productive citizens and of challenging the state to fulfil its God-given responsibility to ensure justice, peace and economic viability prevail (Am 5:24; Rm 13:1-7). In this endeavour, the church must continually bear in mind Bedford-Strohm's (2010:21) call that the church 'be truly light of the world by being itself'. It must be the true light and salt reflecting God's holiness, righteousness, mercy and love at all times. According to Dirkie Smit (2007), the church must introspectively ask:

'Who are we?' Do we embody our vision? Are we the kind of people who live this vision? Are we the kind of community where people are formed who carry, embody, who implement this vision? In other words, are we people of integrity, who practice what we preach? (p. 385)

This means that while the church is made up of fallible people, it must nonetheless demonstrate its authenticity by 'readiness to always and again strive towards its own measures, theologically speaking, to live under the word of God' (Bedford-Strohm 2010:21).

\section{Conclusion}

This article attempted to critically reflect on the usefulness of the anointing of the Pentecostal prophets in responding to poverty in an unjust economic context. The article contended that reliance on the anointing of the prophets does not attend to evil economic structures that are responsible for much of the poverty in Zimbabwe and most of Africa. Therefore, what is needed is not anointing but justice to address the oppressive and exploitative economic structures. In the Bible, true prophets championed justice and equality for the poor and powerless instead of taking advantage of them as is common among many modern Pentecostal prophets. Instead of defending the poor and protecting them from evil oppressors and exploiters, Pentecostal prophets abuse and exploit them in their churches. This must be addressed by adopting a biblically informed understanding of being a Christian prophet.
A truly prophetic pursuit for Africa's economic revival must not be simplistic but be soundly well-informed by the wide breadth of the concerned disciplines. A lack of understanding of economic and political issues results in simplistic solutions, such as anointing or the belief that massive Christianisation in Africa will result in economic revival. Christian leaders need to realise that justice and lawfulness are essential to economic growth. Therefore, the church must resiliently promote justice and lawfulness as an essential route to responding to the endemic poverty in the country.

\section{Acknowledgements}

I wish to thank the peer reviewers for their constructive comments on this article.

\section{Competing interests}

The author declares that he has no financial or personal relationships that may have inappropriately influenced him in writing this article.

\section{References}

Agbiji, O.M. \& Swart, I., 2015, 'Religion and social transformation in Africa: A critical and appreciative perspective', Scriptura 114(1), 1-20. https://doi.org/10.7833/ $114-0-1115$

Banda, C., 2016, 'Empowering hope? Jürgen Moltmann's eschatological challenge to ecclesiological responses in the Zimbabwean context of poverty', PhD thesis, Stellenbosch, Stellenbosch University.

Banda, C. \& Van der Merwe, I.J., 2017, 'The ecclesiological significance of the "African kraal" metaphor in a context of urban poverty in Zimbabwe', Stellenbosch Theological Journal 3(2), 243-267. https://doi.org/10.17570/stj.2017.v3n2.a11

Bedford-Strohm, H., 2008, 'Poverty and public theology: Advocacy of the church in pluralistic society', International Journal of Public Theology 2(2), 144-162. https:// doi.org/10.1163/156973208X290017

Bedford-Strohm, H., 2010, 'Public theology and the economy in a globalizing world', NGTT 51(1\&2), 15-23.

Bedford-Strohm, H., 2013, 'Poverty, wealth and ecology-a theological perspective', Dutch Reformed Theological Journal/Nederduitse Gereformeerde Teologiese Tydskrif: Supplement 5(54), 24-36. https://doi.org/10.5952/54-0-340

Biri, K. \& Togarasei, L., 2013, “....but the One who prophesies, builds the church" Nation building and transformation discourse as true prophecy: The case of Zimbabwean Pentecostal women', in E. Chitando, M.R. Gunda \& J. Kügler (eds.) Prophets, profits and the Bible in Zimbabwe: Festschrift for Aynos Masotcha Prophets, profits and the Bible in Zimbabwe: Festsc
Moyo, pp. 79-94, University of Bamberg, Bamberg.

Bulla, F., 2015, Anointed mantles: A business gimmick, viewed 20 April 2018, http:// www.sundaymail.co.zw/anointed-mantles-a-business-gimmick/

Chaya, V., 2016, Magaya cucumbers raise eyebrows, viewed 22 March 2017 from https://www.dailynews.co.zw/articles/2016/11/28/magaya-cucumbersraiseeyebrows

Chaya, V., 2017, 'Magaya switches to water', viewed 22 March 2017, from https:// www.dailynews.co.zw/articles/2017/01/30/magaya-switches-to-water

Chibango, C., 2016, 'Prosperity gospel, a pathway out of a socioeconomic crisis? Ministries of Walter Magaya, Zimbabwe', An International Journal of Humanities and Social Sciences 3(1), 55-82.

Chitando, E. \& Biri, K., 2016, 'Walter Magaya's Prophetic Healing and Deliverance (PHD) Ministries and Pentecostalism in Zimbabwe: A preliminary study with particular reference to ecumenism', Studia Historiae Ecclesiasticae 42(2), 72-85. particular reference to ecumenism', Studia Historia
https://doi.org/10.17159/2412-4265/2016/829

Chitando, E., Gunda, M.R. \& Kügler, J., 2013, 'Introduction', in E. Chitando, M. Gunda \& J. Kügler, (eds), Prophets, profits and the Bible in Zimbabwe: Festschrift for Aynos Masotcha Moyo, pp. 9-13, University of Bamberg, Bamberg.

Chitando, E. \& Manyonganise, M., 2011, 'Voices from faith-based communities', in T. Murithi \& A. Mawadza (eds.), Zimbabwe in transition: A view from within, pp. 77-111, The Institute of Justice and Reconciliation, Pretoria.

Chitando, E., Manyonganise, M. \& Mlambo, O.B., 2013, 'Young, male and polished masculinities, generational shifts and Pentecostal prophets in Zimbabwe', in E. Chitando, M. Gunda \& J. Kügler (eds). Prophets, profits and the Bible in Zimbabwe: Festschrift for Aynos Masotcha Moyo, pp. 153-170, University of Bamberg, Bamberg.

Chung, F., 2006, Re-living the Second Chimurenga: Memories from the liberation struggle in Zimbabwe, Nordic African Institute, Uppsala.

De Gruchy, J.W., 1995, Christianity and democracy: A theology for a just world order, David Philip, Cape Town. 
Deuschle, T., 2003, Building people, building dreams: How a church can change a nation, Hear the Word, Harare.

Jones, J.L., 2010, "Nothing is straight in Zimbabwe": The rise of the kukiya-kiya economy 2000-2008', Journal of Southern African Studies 36(2), 285-299. https:// doi.org/10.1080/03057070.2010.485784

Korten, D.C., 1990, Getting to the 21st Century: Voluntary Action and the Global Agenda, Kumarian, West Hartford, CT.

Kretzschmar, L., 2002, 'Authentic Christian leadership and spiritual formation in Africa', Journal of Theology for Southern Africa 113, 41-60.

Longenecker, B.W., 2010, Remember the poor: Paul, poverty and the Greco-Roman world, W.B. Eerdmans, Grand Rapids, MI.

Magaya, W., 2015a, Prophet Walter Magaya speaks about the anointing oil, viewed 19 March 2018, from http://magaya.hurukuros.com/2015/10/prophet-waltermagaya-speaks-about.html

Magaya, W., 2015b, Drop the old donkey's jawbone, viewed 19 March 2018, from http://magaya.hurukuros.com/2015/03/sermon-drop-old-donkeys-jawbone. htm

Magaya, W., 2015c, Thy Kingdom come, viewed 28 January 2018, from http://magaya. hurukuros.com/2015/05/prophet-w-magaya-teaching-on-thy.html

Magaya, W., 2016a, Power of the anointing, viewed 23 March 2018, from https:// www.youtube.com/watch?v=PgTfFrD6pGA

Magaya, W., 2016b, Overtake and maintain, viewed 19 March 2018, from http:// magaya.hurukuros.com/2016/10/prophet-w-magaya-sermon-overtake-and.htm

Magezi, V. \& Manzanga, P., 2016, 'Prosperity and health ministry as a coping mechanism in the poverty and suffering context of Zimbabwe: A pastora evaluation and response', In die Skriflig 50(1), a2076. https://doi.org/10.4102/ids. v50i1.2076

Mahohoma, T.C., 2017, 'A theological evaluation of God business: A case study of the Prophetic healing and deliverance Ministries of Zimbabwe', HTS Teologiese sStudies/Theological Studies 73(2), 4529 . https://doi.org/10.4102/hts.v73i2.4529

Manyeruke, C. \& Hamauswa, S., 2013, 'Prophets and politics in Zimbabwe', in E. Chitando, M. Gunda \& J. Kügler (eds.), Prophets, profits and the Bible in Zimbabwe: Festschrift for Aynos Masotcha Moyo, pp. 281-297, University of Bamberg, Bamberg.

Maxwell, D., 1998, “'Delivered from the spirit of poverty?": Pentecostalism, prosperity and modernity in Zimbabwe,' Journal of Religion in Africa 28(3), 350-373. https:// doi.org/10.2307/1581574
Mazingi, L. \& Kamidza, R., 2011, 'Inequality in Zimbabwe', in H. Jauch \& D. Muchena (eds.), Tearing us Apart: Inequalities in Southern Africa, pp. 322-382, Open Society Initiative for Southern Africa, viewed 13 May 2016, from http://www. osisa.org/sites/default/files/sup_files/chapter_5_-_zimbabwe.pdf

Methula, D.W., 2014, 'Engaging in the struggle for economic justice in the streets of the City of Tshwane', Missionalia 42(1-2), 107-119. https://doi.org/10.7832/42 $1-2-50$

Mpofu, B., 2011, Some perceptions on the poverty question in Zimbabwe, viewed 27 August 2014, from. http://www.solidaritypeacetrust.org/download/essays/ The $\% 20$ Poverty $\% 20$ Question $\% 20$ in $\% 2$ 20Zimbabwe.pdf

Mugambi, J.N.K., 1995, From liberation to reconstruction: African Christian theology after the Cold War, East African Educational, Nairobi.

Myers, B.L., 2011, Walking with the poor: Principles and practices of transformational development, Revised \& Expanded Edition, Orbis, Maryknoll.

Nürnberger, K., 1994, 'The task of the church concerning the economy in a postapartheid South Africa', Missionalia 22(2), 118-146.

Raftopoulos, B., 2009, 'The crisis in Zimbabwe, 1998-2008', in B. Raftopoulos \& A. Mlambo (eds.), Becoming Zimbabwe: A history from the pre-colonial period to 2008, pp. 201-232, Weaver, Harare.

Rupapa, T. \& Shumba, D., 2014, Thousands queue for Makandiwa's anointing oil, viewed 22 March 2017, from http://www.herald.co.zw/thousands-queue-formakandiwas-anointing-oil

Smit, D., 2007, Essays in public theology: Collected Essays 1, in E.M. Conradie (ed), African Sun Media, Stellenbosch.

Speckman, M.T., 2007, A biblical vision for Africa's development?, Cluster, Pietermaritzburg,

Strydom, J.G., 2000, 'Prophetic perspectives on social justice: The eighth century prophets', in J.G. Strydom \& W.J. Wessels (contributors), Prophetic perspectives on power and social justice, pp. 137-244, Biblia, Pretoria.

The Herald, 2015, Prophet Magaya buys First Lady's book for \$50,000, viewed 13 November 2015, from http://www.herald.co.zw/prophet-magaya-buys-firstladys-book-for-50-000/

Transparency International Zimbabwe (TZI), 2017, Understanding bribery in Zimbabwe, viewed 23 March 2018, from http://tizim.org/?p=528

Vengeyi, O., 2011, “'Zimbabwean poverty is man-made!" Demystifying poverty by appealing to the prophetic book of Amos', Scriptura 107, 223-237. https://doi. org/10.7833/107-0-138 